\title{
Seattle Cancer Care Alliance
}

National Cancer Institute

\section{Source}

National Cancer Institute. Seattle Cancer Care Alliance. NCI Thesaurus. Code C103855.

A world-class cancer treatment center that unites doctors from Fred Hutchinson Cancer Research Center, UW Medicine and Seattle Children's. 